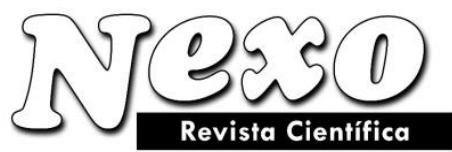

ISSN-E 1995-9516

Universidad Nacional de Ingeniería COPYRIGHT @ (UNI). TODOS LOS DERECHOS RESERVADOS http://revistas.uni.edu.ni/index.php/Nexo https://doi.org/10.5377/nexo.v34i05.13107

Vol. 34, No. 05 (Especial), pp. 45-55/Diciembre 2021

(c) (i) () $\ominus$

\title{
Application of parametric design and digital fabrication: the solution for the current crises and emergencies
}

\section{Aplicación del diseño paramétrico y fabricación digital: la solución ante las crisis y emergencias actuales}

\author{
Mauricio Díaz Valdés \\ Escola Tècnica Superior d'Arquitectura del Vallès. Universitat Politècnica de Catalunya \\ Barcelona, Spain \\ mdiaz@acier.com.mx
}

(recibido/received: 12-agosto-2021; aceptado/accepted: 19-noviembre-2021)

\begin{abstract}
During the next decades the construction will have to face many problems that never had inferred, it must reinvent itself to adapt to the new needs that it currently demands because it consumes too many energetic resources, it generates excess of $\mathrm{CO} 2$ emissions, consumption of natural resources and every day the construction is more expensive. The United Nations 2030 Agenda announced the objectives for sustainable development, this to try to mitigate the effects of climate change; The Coronavirus pandemic made humanity reflect on the emergencies that we must face and left us reflecting that we are not prepared for an emergency or crisis; These are key points that we must address to develop the new architecture. If we analyze the history of architecture, we can see that technology and science has always been a catalyst for humanity and has generated great solutions to the problems that befall us, this should motivate us to use technology and software in our favor. Therefore, we must prepare and generate new solutions, innovations and technology that focus on solving the new needs that architecture demands. The question is: how we can solve these problems? The answer is through digital fabrication and parametric design. It is important to emphasize and make it clear, we cannot continue to build as we have been doing in the past century, our practices and approaches must change, and it is urgent to rethink the role of the architecture today.
\end{abstract}

Keywords: Environment, digital fabrication, parametric design, computer design, crises

\section{RESUMEN}

Durante las próximas décadas la construcción tendrá que afrontar muchos problemas que nunca habían inferido, debe reinventarse para adaptarse a las nuevas necesidades que demanda 
actualmente porque consume demasiados recursos energéticos, genera exceso de emisiones de $\mathrm{CO} 2$, exceso de consumo de recursos naturales y cada día la construcción es más cara. La Agenda 2030 de las Naciones Unidas anunció los objetivos de desarrollo sostenible, esto para tratar de mitigar los efectos del cambio climático; la pandemia de coronavirus hizo reflexionar a la humanidad sobre las emergencias que debemos afrontar y nos dejó reflexionando que no estamos preparados para una emergencia o crisis; estos son puntos clave que debemos abordar para desarrollar la nueva arquitectura. Si analizamos la historia de la arquitectura, podemos ver que la tecnología y la ciencia siempre ha sido un catalizador para la humanidad y ha generado grandes soluciones a los problemas que nos acontecen, esto debería motivarnos a utilizar la tecnología y el software a nuestro favor. Por ello, debemos preparar y generar nuevas soluciones, innovaciones y tecnología que se enfoquen en dar solución a las nuevas necesidades que demanda la arquitectura. La pregunta es: ¿cómo podemos solucionar estos problemas? La respuesta es a través de la fabricación digital y el diseño paramétrico. Es importante enfatizar y dejar claro, no podemos seguir construyendo como lo hemos venido haciendo en el siglo pasado, nuestras prácticas y enfoques deben cambiar, y es urgente repensar el papel de la arquitectura hoy.

Palabras claves: Medio ambiente, fabricación digital, diseño paramétrico, diseño por computadora, crisis.

\section{INTRODUCTION}

This paper seeks to publicize and make reflection about the new needs that demand architecture today and how we can generate a link between the practices and the objectives of Agenda 2030 of the UN to try to generate sustainable practices with the environment and society and analyze how throughout history humanity has experienced different emergencies that have led it to modify the way of living and developing architecture. It is a reality that architecture must currently be redirected due to its great impact that it generates on the environment, and this should motivate the development of new practices that integrate technology and computational design. The key message of this paper is action; the most important thing to do is start something. During the next decades, new scenarios will be presented that have never worried humanity and that, unfortunately, architecture occupies a great place within the main emitters of $\mathrm{CO} 2$ to the environment.

Without a doubt, the integration of these new practices is of global interest that urgently must be developed everywhere in order to be able to generate new proposals regarding the new emergencies and crises that affect humanity. Current emergencies and climate change require that we rethink design and focus on creating buildings that integrate digital fabrication and parametric design; Through research, architecture must work in a multidisciplinary way to find new solutions to these new problems.

During 2020 we faced one of the largest pandemics in the world, COVID-19 that marked the history of humanity and most of the world's inhabitants contracted the disease; According to UNESCO $90 \%$ of all COVID-19 infections were registered in cities, urban areas have become the epicenter of the pandemic. This should be a starting point for prepare us for the following emergencies and try to integrate practices that benefit humanity. The digital fabrication and parametric design, will be able to face the new emergencies and crises that affect humanity; Technology and software today must be inherent to architecture because its applications and results will generate great contributions since innovative construction techniques are used and it is projected through software that makes the result more environmentally friendly. 
At a time when the world's headlines are dominated by grand challenges such as ecological dilemmas, economic crises and resource shortages, the capacity to develop innovative solutions to problems and sometimes even re-define the problems has never been so critical (Lee, 2020). During the last decades we have reviewed how these innovative practices have been integrated into architecture and the paradigms of new technologies are being broken and considering more countries to develop these technologies in their respective communities. The above is a key point regarding the new emergencies that humanity is facing and how architecture must be an agent of change for humanity. Today humanity demands actions and new designs that integrate technological innovations and sustainable practices. As an example, we have that during the COVID 19 pandemic, cities were the ones that were most affected by the pandemic, the above shows us that we are not prepared for current emergencies and crises.

Urban areas today support 55\% of the world's population and cities are expected to support $70 \%$ of the world's population by 2050. This exponential growth must respond effectively and creatively to the new emergencies that we currently face and think ahead regarding the new needs that humanity will need in the coming decades (table1).

Table 1: The worlds ten largest cities in 2018 and 2030 by the UN

\begin{tabular}{|c|c|c|c|c|}
\hline $\begin{array}{l}\text { City } \\
\text { size } \\
\text { rank }\end{array}$ & City & $\begin{array}{l}\text { Population in } \\
2018 \\
\text { (thousands) }\end{array}$ & City & $\begin{array}{l}\text { Population } \\
\text { in } 2030 \\
\text { (thousands) }\end{array}$ \\
\hline 1 & Tokyo, Japan & 37468 & Delhi, India & 38939 \\
\hline 2 & Delhi, India & 28514 & Tokyo, Japan & 36574 \\
\hline 3 & Shanghai, China & 25582 & Shanghai, China & 32869 \\
\hline 4 & $\begin{array}{l}\text { São Paulo, Brazil } \\
\text { Ciudad de México (Mexico City), }\end{array}$ & 21650 & Dhaka, Bangladesh & 28076 \\
\hline 5 & Mexico & 21581 & Al-Qahirah (Cairo), Egypt & 25517 \\
\hline 6 & Al-Qahirah (Cairo), Egypt & 20076 & Mumbai (Bombay), India & 24572 \\
\hline 7 & Mumbai (Bombay), India & 19980 & $\begin{array}{l}\text { Beijing, China } \\
\text { Ciudad de México (Mexico City), }\end{array}$ & 24282 \\
\hline 8 & Beijing, China & 19618 & Mexico & 24111 \\
\hline 9 & Dhaka, Bangladesh & 19578 & $\begin{array}{l}\text { São Paulo, Brazil } \\
\text { Kinshasa, Democratic Republic of the }\end{array}$ & 23824 \\
\hline 10 & Kinki M.M.A. (Osaka), Japan & 19281 & Congo & 21914 \\
\hline
\end{tabular}

\section{STATE OF ART}

Disproportionate population growth, climate change, new technologies, global crises and emergencies are happening at the same time, motivating the generation of new solutions to these problems. As the mathematician Richar Hamming stated: "the purpose of computing is insight, not numbers"; It is so integrating these solutions to cities, they provide opportunities for cities to increase the quality of life of their inhabitants and mitigate the effects of climate change; therefore, it is necessary to integrate these practices over the next decades. Importantly, cities are the primary hub for digital fabrication and parametric design to develop and integrate these innovative practices. Emergence is a concept that appears in the literature of many disciplines, and is strongly correlated to evolutionary biology, artificial intelligence, complexity theory, cybernetics and general system's theory. It is a word that is increasingly common in architectural 
discourse, where too often it is used to conjure complexity but without the attendant concepts and mathematical instruments od science (Weinstock, 2012).

We are currently in a period of transition for all humanity due to the new emergencies and crises that the inhabitants of the earth are facing and in the same way we are going through the fourth Industrial Revolution which is marked by emerging technological advances in various fields, which They include: robotics, artificial intelligence, nanotechnology, quantum computing, biotechnology, the Internet of things (IoT), 3D printing, and autonomous vehicles.

Emergence is generally understood to be a process that leads to the appearance of structure not directly described by the defining constraints and instantaneous forces that control a system. Over time "something new" appears at scales not directly specified by the equations of motion. An emergent feature also cannot be explicitly represented in the initial and boundary conditions. In short, a feature emerges when the underlying system puts some effort into its creation. (Crutchfield, 1994).

The Secretary General of the United Nations, António Guterres affirms that: technology is on our side to combat the effects of climate change, "and referring to cities, he states: 2021 will also be critical in advancing the New Urban Agenda. The world's cities are fundamental frontlines on sustainable development vulnerable to disaster yet vectors of innovation and dynamism. Let us not forget that more than $50 \%$ of humankind already lives in cities and this number will reach almost $70 \%$ in 2050 .

The dominant mode of utilizing computers in architecture today is that computerization; entities or process that are already conceptualized in the designers mind are entered, manipulated, or stored on a computer system. In contrast, computation or computing, as a computer-based design tool is generally limited. The problem with this situation is that designers do not take advantage of the computational power of computer: (Kostas Terzidis 2006).

After the Industrial Revolution, construction was modified by the integration of new construction techniques and materials, this gave rise to generating works that will be a milestone for architecture and marked a century due to their great contributions; steel, glass and cement were the great materials that were integrated during the twentieth century and that through technology gave rise to new ways of developing architecture. If we analyze modern architecture and the pioneers of this time, we will notice that technology and materials were crucial for them to develop, but on the other hand we abused the consumption of these materials and there was no knowledge regarding the effect of making these materials and the effect after use. During the last decades of the twentieth century, new research and knowledge regarding climate change and emergencies that were of interest to humanity began to be developed.

The future of architecture and the built environment depends on these advanced building technologies and construction techniques, and innovative practices and research organizations are adopting and implementing them for various types of buildings, installations and applications: (Aksamija, 2016). 


\section{EMERGENCIES THROUGH HISTORY: EFFECTS IN THE ARCHITECTURAL DESIGN}

The crises and emergencies (table 2) sometimes transformed the societies in which they appeared and, quite possibly, have decisively changed or influenced the course of history. These times that marked humanity have modified the way of developing architecture due to the needs that humanity demands, through creativity and emergency we have managed to adapt to solve human needs. The coronavirus, the Spanish flu and the black plague are examples of crises that have led humanity to rethink its future on earth and rethink its actions; and through these pandemics, new ways of developing architecture have been generated in the face of new emergencies.

The dean of the architecture school of the Royal Danish Academy of Fine Arts, Jakob Brandtberg affirms that: "In the last 150 years, life expectancy has increased from around 45 to 80 years and it is fair to say that half of that is due to architecture and engineering and the other half, to the medical community", This highlights the obligation of architecture to focus on the needs of each era and satisfy them through architectural design.

On March 4, 2018, the first centenary of the pandemic was celebrated of Spanish flu that prior to the Coronavirus was the most serious flu that the human species has known. The 1918 Flu pandemic in a singularly short space of time swept the entire planet, ending the lives of children, young people, the elderly and pregnant women; altering of life and social activity such that in many affected countries even the Population demographics were severely affected. The Spanish Flu pandemic is only comparable to that of the Black Death of the fourteenth century, the flu between 1918 and 1919 affected 500 of the 1.8 billion who inhabited the world then, which represented an incidence of $25-30 \%$ of the world population. Based on data from developed countries that in that time had adequate records, it is estimated that between 50 and 100 died millions of people.

In the hot summer of 1858 , temperatures of more than $30^{\circ} \mathrm{C}$ caused the distinctive aroma of the River Thames for centuries used as a dump for human, animal and industrial waste invaded London and forced members of the new Parliament to finally take action " for the purification of the Thames and the drainage of the metropolis ". The purpose of the aqueduct was "the merciful reduction of the epidemic" of the most feared disease, cholera, which affected rich and poor and for which there was no cure. And he did it: in 1866 most of London was saved from a cholera outbreak that affected only those who lived in the only area that remained to be connected to the network.

These are some of the examples of some crises that humanity has gone through and that have marked history. Currently the crises and emergencies that humanity is going through are different and this should motivate architecture to be able to focus on generating new architectural solutions that integrate science, technology and software in order to mitigate contemporary adversities.

Crises often serve humanity to generate great contributions, technologies and innovations that modify the scenario of each era; These solutions emerge when humanity must leave its comfort zone and must make the appropriate changes to its current situation. During the history of humanity, we have gone through different scenarios that have marked and this has generated a change in our way of thinking and the effect of our actions; We have gone through wars, 
pandemics, revolutions, droughts and humanity has always sought to adapt to the adversities that affect it. But at present we must face several scenarios and try to solve ourselves through design, technology and creativity, within this paper we will talk about these great opportunities that we have and how we can apply them to the crises that humanity is currently facing.

Table 2: Summary of the pandemics that have marked humanity and what contributions they have generated to architecture

\begin{tabular}{|c|c|c|c|}
\hline Crises & Date & About & Contributions to architecture \\
\hline Coronavirus & $\begin{array}{l}\text { Early } 2020 \\
\text { - present }\end{array}$ & $\begin{array}{l}\text { It is a respiratory viral disease belonging to the same genetic } \\
\text { family as the SARS-CoV, which emerged in China a in } 2002 \text {. } \\
\text { The first has its origin in bats who in turn transmitted the virus } \\
\text { to humans through zoonoses. According to the WHO, it is } \\
\text { estimated that about } 10 \% \text { of the world's population, this is } \\
\text { about } 780 \text { million people }\end{array}$ & $\begin{array}{l}\text { 1. Urban development and public space will be } \\
\text { modified in order to have more open and } \\
\text { healthy spaces. } \\
\text { 2. Integration of new architectural innovations } \\
\text { focused on doing more with less. } \\
\text { 3. Design and reformulation of construction } \\
\text { laws that integrate the needs of the pandemic } \\
\text { 4. Development of lightweight structures } \\
\text { focused on any emergency and with } \\
\text { contemporary materials }\end{array}$ \\
\hline Spanish flu & $\begin{array}{l}1918- \\
1920\end{array}$ & $\begin{array}{l}\text { Between } 1918 \text { and } 1920 \text { killed more than } 40 \text { million people } \\
\text { around the world. The exact figure for the pandemic, which is } \\
\text { considered the most devastating in history, is unknown. A } \\
\text { century later, it is still not known what was the origin of this } \\
\text { epidemic that did not understand borders or social classes. }\end{array}$ & $\begin{array}{l}\text { 1. Spaces focused on health and hospitals were } \\
\text { modified, generating research centers of } \\
\text { different specialties and decentralizing health } \\
\text { 2. Improvement and planning of urban space } \\
\text { and better sewerage system in the most } \\
\text { important cities of the world }\end{array}$ \\
\hline Black Death & $\begin{array}{l}1347- \\
1353 .\end{array}$ & $\begin{array}{l}\text { Spread rapidly through the regions of the Mediterranean basin } \\
\text { and the rest of Europe within a few years. It is difficult to } \\
\text { know the number of deaths, but contemporary models estimate } \\
\text { them at } 80 \text { to } 200 \text { million in Eurasia and North Africa. It } \\
\text { would have caused the death of between } 30 \% \text { and } 60 \% \text { of the } \\
\text { population of Europe. }\end{array}$ & $\begin{array}{l}\text { 1. Cities are beginning to take into account } \\
\text { the guidelines to have wider avenues in } \\
\text { order to have healthier and cleaner spaces } \\
\text { 2.New drainage and sewerage systems } \\
\text { begin to be developed }\end{array}$ \\
\hline
\end{tabular}

\section{METHODS}

In recent years architects have adopted digital software tools for generating design in an unprecented manner, but they seem to have stopped short of exploring the effects of the novel design possibilities offered by the digital beyond the boundaries of their own profession.

Since the introduction of CAD / CAM technologies in the nineties, the paradigms of architecture were questioned and new ways of representing were included in architecture studies, as is the case of the office of Gehry and associates, the same as was one of the first to implement digital processes for design. These events are what allow the introduction of these technologies into teaching practices and give way to the creation of the first digital fabrication laboratories that question the new role of the architect in the design and construction processes and open the way to a world of possibilities through workshops that allow exploring the different spatial and volumetric possibilities, as happens in the different laboratories created in a small number of universities. Computer-aided design (CAD) and computer-aided manufacturing (CAM) have become the most important tools of the 21st century designer, as both mark a revolution in the way of doing architecture by expanding creative and innovation possibilities. in the field of design, since with the availability of cheaper machinery, the manufacture of unique pieces is no 
longer exclusive to large companies; This technology has been made available to more people. As one of the emerging Computer-Aided Design (CAD) technologies for digital design and visualisation in the Architecture, Engineering and Construction (AEC) domain, parametric design potentially offers an innovative way of generating new design solutions. (Lee, 2014).

Digital fabrication and parametric design in architecture has the particularity of allowing experimentation and, with it, invention and innovation in design proposals. How to most effectively utilise emerging Computer-Aided Design (CAD) technologies so as to better serve the needs of digital design in the Architecture, Engineering and Construction (AEC) domain has been a significant area of research. Recently, parametric design - one of the emerging CAD technologies has attracted a strong interest from designers and design students alike specifically for the "creativity" it supports, as evidenced in the unique forms or styles it generates. Parametric design as a new approach to designing, the understanding of its unique method for generating design solutions and alternatives and the understanding of its impact on the design processes and design outcomes, is critical for its adaption in both design industries and design schools (Lee, 2014).

Digital fabrication is the process of project development of an element, based on the use of digital tools during the entire production process, from the conception of the initial idea to the completion of the product. Digital fabrication in architecture is a relatively recent phenomenon, which has evolved over the last 15 years to become a critical aspect in today's architecture due to the wide variety of possibilities it has opened up. By digital fabrication we can understand all that material manufacturing process based on digital techniques and software, following subtractive or additive procedures. These new development tools in architecture were first introduced in a university in the late 1990s, by Professor William Mitchel of MIT in the School of Architecture and Planning, who founded the first laboratory of digital fabrication, this laboratory in its early days. It had a machine for deposition fusion modeling (FDM) and a laser cutter, in addition to some machines accessible thanks to the mechanical engineering department, this equipment was mostly used in the manufacture of scale models for Ph.D. students.

As the knowledge about the use parameters was assimilated, a greater number of students used them, and the acquisition of new machines became relevant. One of its virtues is that it is intimately linked to material knowledge and experimentation, just as architecture is with materials, which is why current technology opens a channel of reunion between designer and material, which allows us to approach a craft work in design projects that have been neglected for decades. "Making becomes knowledge or intelligence creation. In this way thinking and doing, design and fabrication, and prototype and final design become blurred, interactive, and part of a non-linear means of innovation:' As it does for the large-scale work of Frank Gehry and others, the digital environment allows architects to take control of the building process. Several groundbreaking projects helped instigate this avenue of design research and shape a new generation of architects (Iwamoto, 2009).

These examples show the importance that technology has acquired within architecture, and more recently within teaching practice, since it allows a visualization of a 1: 1 scale model that facilitates the compression of space. Similarly, as a result of the implementation of technologies for digital fabrication and parametric design, the production of models with individual parts has become feasible since, unlike industrialization, in digital fabrication the production of unique 
models does not imply higher costs. of production. Finally, CAD / CAM systems facilitate the multidisciplinary work that can be experienced in FabLabs. Over the last half century, architecture has been slowly adapting its represantional practices from the conception of objects of sensory engagement to the construction of systems of formally described relationships. This shift from object description to definition of a dynamical space of design posibilitiees, or state space, we call computational design (Burry, 2011).

Computation has a profund impact on both preconception and realization of architectural form, space and structure. It shifts that way one perceives form, the way in which form is purposed, and the way in which form is produced. The fundamental concepts which underlies computational theory and techniques expose form as a subsidiary component of environment as a complex web of energies in dynamic exchange of both generation and degeneration (Menges, 2011). Parametric design and digital fabrication technologies have their origin in the years central 20th century as a result of the convergence of computer technology and numerical control machinery. Between the decades of 1970 and 1980, with the cheapening of computers milestone of the IBM PC of 1981, the development of CAM software and the integration of hardware and software with CNC machinery (computer numeric control), CAD practices were consolidated. / CAE / CAM (Computer Assisted Design / Engineering / Manufacturing), particularly in the aerospace, marine and automotive industries. The possibility of creating elements directly from the design information has precipitated the transformation of disciplines, even allowing the designer to be more involved with the entire process from idea to final product, as described by Lisa Iwamoto: For many years, as the process of making drawings steadily shifted from being analog to digital, the design of buildings did not really reflect the change. CAD replaced drawings with parallel rule and lead pointer, but buildings looked pretty much the same. This is not so surprising - one form of two-dimensional representation replaced another. It took three-dimensional computer modeling and digital fabrication to energize design thinking and expand the boundaries of architectural form and construction.

The use of parameters and the automation of some tasks open up infinite design possibilities; in a vision of architecture in which technologies can efficiently carry out tasks that were previously typical of the architect-designer. The Spanish Architect Ion Cuervas-Mons, shows a challenging idea of parametric architecture applied to citizen participation. He mentions that one could imagine a software that allows everyone to design their own home, simply changing some parameters according to the wishes of each one. One of the greatest advantages of parametric design is the symbiosis between disciplines, which allows us to integrate structural and social criteria, flow simulations, etc. This need to integrate diverse disciplines is a product of the complexity of society. Until now, parametric design has been presented as an option for design experimentation, due to the difficulties and costs that its materiality represents, in order to the three-dimensional model is not just a virtual model but a tool capable of giving us results and information to achieve more realistic designs that propose results forceful. Programming is writing algorithms that either build models or work as update algorithms in their own right. Both construction and programming are foreign to most designers. The last half of the 20th Century saw a dramatic decline in teaching the closest geometric topic, descriptive geometry; and a modest and erratic introduction of programming. Parametric modeling and contemporary design conspire to demand both of these skills. Before addressing either of the technical skills of programming or geometry (Woodbury,2010). 


\section{RESULTS AND DISCUSSION}

At this day, digital fabrication and parametric design has become the biggest change within the architectural project's shaping processes. The techniques used by digital fabrication force designers and architects to reflect on their design process, developing new methodologies and incorporating non-linear approaches. The potential of digital fabrication and parametric design is realized when generation, integration and different strategies and tactics are combined in a unison within the architectural project. The key to this development is the interest in the exploration of materials, and how design tries to express through this development. The creative use of the computer for the development of digital tools has been key to creating platforms that connect design and fabrication.

Parametric design could also potentially contribute to the development of a new methodology for architectural design and research, highlighting a wide range of impact from design optimization to design innovation in terms of complexity and emergence of forms (Lee,2014).

It is thanks to these initiatives that, at the end of the nineties, technologies were incorporated, not only within architecture studies but also in teaching; The tools allow the modernization of variable surfaces and, in addition, the relationship between the representation of architecture production has changed, introducing a process that highlights a practical phase that involves the creation of models with a certain amount of variable parameters and their relationships, with spatial results. virtually and a building manufacturing phase, manufacturing elements that can be numerically controlled. This new. way of acting in the creation of architecture is known as CNC (Computer numerically controlled) or F2F, abbreviation of the expression in English "file to Factory", which in the same way explains the change in the relation of the architect who now he is able to build what he designs.

The integration of digital fabrication and parametric design in architecture, from the concept to the development of full-scale models is a much more ambitious goal than the use of the computer as an instrument, which involves different evolutionary tasks of a process in which creativity and technology must work synergistically in parallel times. Traditionally the world of industry and construction has been viable through the mass production of elements and the union of standardized elements. Digital techniques have transformed this process, and today it has become an element of experimentation available to architects, opening a field opens not only to project a space, but also to explore with new materials that boost creativity and efficiency. The design strategies and tactics provided by digital fabrication affect the space between project-build, allowing architects to be more involved in the manufacturing process. Digital fabrication does not offer an "instruction book", but rather provides another point of view. In general, it can be said that the possibilities that digital manufacturing offers are sectioning, modular, folding, contouring and forming. The combination of them is part of the project strategy and the developed tactics that demands the architecture of today.

The current importance of digital fabrication in universities is currently increasing because they are the bases of the academic and professional life of architects and engineers. Innovation in the student work and the didactic course design is inspired by the notion that "we can use digital fabrication as a catalyst for design instead of a means of production (Cheng,2009). 


\section{CONCLUSION}

During the last two decades, research in architecture has taken different perspectives and has been influenced by other disciplines, such as the development of bio-materials, new construction techniques and the development of new software; This has motivated the generation of new research on the future of architecture. The real challenge to face the new emergencies and crises is to think as humanity and architecture have never done, we must have a completely multidisciplinary vision about actions. The architectural training must develop technical, scientific and technological skills to carry out construction projects. The new digital fabrication machines and parametric design allow the elaboration of material models of the designs, as well as industrialized construction elements, generating new capacities that must be adequately integrated into professional education.

After the years we have gone through different emergencies and crises that have marked humanity; Since the beginning of humanity, we seek our safety and well-being in the caves and we begin to develop new skills and techniques to continue surviving, later we have gone through wars, droughts, diseases and humanity has identified the problems to provide solutions to these adversities. Unfortunately, today the scenario is very different from how it was before, several emergencies and crises that have marked the history of humanity have come together and it is obvious that humanity is not yet prepared for these adversities that we currently face, as a clear example is the Covid-19 pandemic that emerged in 2020. This crisis is a clear example of everything that can happen to humanity during the next decades, this must be the key point to be able to generate great proposals and integrate sustainable practices to cities; These forces us to focus our attention on cities because they represent the central point of change and the integration of innovative practices and should motivate government and state entities to try to integrate new sustainable solutions.

An undeniable truth is that the future of architecture will depend on the advances of new materials, construction systems and software to be able to face the new contemporary crises and emergencies. We are in a crucial time for humanity and architecture; the old construction models of the last two centuries are related to aesthetics, ornament, theory and practices limited to the past and present. But currently architecture must have a vision focused mainly on the future and the events of the coming decades. The real problem we face is: how do we transform our profession that is very framed by the past and intuition in order to have a more scientific and technological vision? Fuller Buckminster stated: "A designer is an emerging synthesis of artist, inventor, mechanic, objective economist and evolutionary strategist". The current transition between parametric design and digital fabrication represents a great change for architecture today due to the methods, technologies, materials and software that they integrate and how these practices can be a great solution to current crises and emergencies, because today we must think with a more ecological perspective. Through the minimization of non-ecological practices and more economical processes we will be able to achieve the goal of trying to mitigate the effects of the environment.

Despite the difficulties, digital fabrication and parametric design provide multiple advantages, such as a decrease in occupational accidents, a reduction in waste on site, a lower $\mathrm{CO} 2$ footprint, a reduction in noise at the construction site, and a lower environmental impact, the reduction of construction times, cost control, the improvement of family conciliation, the stabilization of jobs 
and their specialization, research, the continuous improvement of processes. On the other hand, it is important to highlight that during the next few years we must generate new proposals that integrate all populations and carry out housing and architectural proposals that take into account the habitable needs of human beings; Through digital fabrication and parametric design we will be able to generate new solutions that satisfy the habitable needs of the different societies of the world.

\section{REFERENCIAS}

Aksamija, Ajla. (2016) Integrating innovation in architecture. Design Methods and technology for progressive practice and research. John Wiley \& Sons.

Burry, Jane (2011) Philosophy of mathematics for computational design: spatial intuition versus logic. John Wiley and Sons.

Cheng, Nancy Yen-Wen (2020) Serendipity and Discovery in a Machine Age: Craft and a CNC Router. ACADIA 2009: reform (): Building a better tomorrow. http://cumincad.scix.net/data/works/att/acadia09_284.content.pdf

Crutchfield, James P. (1994) Is anything ever new? MIT Press.

Iwamoto, L.(2009) Digital Fabrication: Architectural and Material Techniques. Princeton Architectural Press

Lee, Hyun (2014) Parametric design strategies for the generation of creative designs. International Journal of Architectural Computing. doi.org/10.1260/1478-0771.12.3.263

Lee, Hyun (2020) Design Thinking: Creativity, collaboration and culture. Springer International Publishing

Megnes, Achim. (2011) Computational Design Thinking. John Wiley \& Sons

Michael Weinstock (2012) Morphogenesis and emergence. AD Wiley

Terzidis, Kostas. (2006) Algorithmic Architecture. Architectural Press

Woodbury, Robert (2010) Elements of parametric design, Abingdon

\section{AUTHOR'S REVIEW}

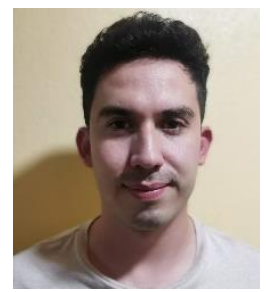

Mauricio Díaz Valdés. I am an architect, technologist and researcher exploring how emerging technologies, materials, science empower design innovation and sustainable practices. I have a M.Arch degree from the National Autonomous University of Mexico and I'm about to start my second master's degree in parametric design at the Universitat Politècnica de Catalunya. The research I carry out has the implementation of integrating technological, digital/innovative fabrication and sustainable solutions to architectural design with a multidisciplinary perspective. I am the founder of the international Seminar: The future of architecture; whose purpose is to make known theories, knowledge and projects that favor the architecture of the twenty-first century. 